Journal of Science

and Engineering

Full Paper

\title{
ANALISIS KUALITAS LAYANAN E- \\ GOVERMENT MENGGUNAKAN METODE SERVQUAL (STUDI KASUS KANTOR SAMSAT KOLAKA)
}

Nurfitria Ningsi ${ }^{a^{*}}$, Gusnawati ${ }^{b}$, Noorhasanah. Zc nurfitrianingsi35@gmail.com

\author{
Article history \\ Received \\ 3 Oktober 2020 \\ Accepted \\ 6 Mei 2021
}

abcProgram Studi Sistem Informasi Universitas Sembilanbelas November Kolaka, Sulawesi Tenggara Indonesia

\section{Graphical abstract}

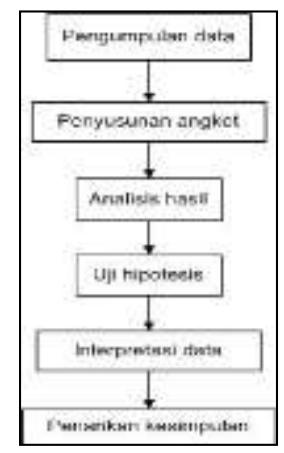

\begin{abstract}
The objective of this study is to find out the service quality of the motor vehicle tax information system at the SAMSAT Kolaka Office, where the analysis model used is five-dimensional SERVQUAL with a total of 100 respondents. Based on the results of statistical calculations there is a gap between perceptions and expectations of the service quality of the vehicle tax information system for each of the dimensions of Servqual, where the tangibels variable there is an average gap of $(-0.415)$, reability $(-0.19)$, responsiveness (-0.28667), assurance (-0.26667), empathy (-0.17), and Y variable (-0.36571). From the multiple regression calculations using SPSS, there are several variables that have no effect on customer satisfaction because a significant level value greater than 0.05 includes assurance variable with a significant value of 0.590 and empathy variable with a significant value of 0.113 . the addition of other variables in exploring consumer satisfaction with the quality of motor vehicle tax information system services.
\end{abstract}

Keywords: service quality, e-government, SIZ, Vehicle Tax

\begin{abstract}
Abstrak
Objektif dari studi ini adalah Untuk mengetahui kualitas pelayanan sistem informasi pajak kendaraan bermotor pada Kantor SAMSAT kolaka, dimana model analisis yang digunakan adalah lima dimensi SERVQUAL dengan total Responden 100 orang. Berdasarkan hasil perhitungan statistik terdapat gap antara persepsi dan harapan dari kualitas layanan sistem informasi pajak kendaraan untuk masing-masing dimensi Servqual, dimana pada variabel tangibels terdapat rata-rata gap sebesar (-0.415), reability (-0.19), responsiveness (-0.28667), assurance (-0.26667), empathy (-0.17), dan variabel Y sebesar (-0.36571). Dari perhitung regresi berganda yang menggunakan SPSS ada beberapa variabel yang tidak berpengaruh terhadap kepuasan konsumen karena nilai taraf signifikan yang lebih besar dari 0.05 diantaranya variabel assurance dengan nilai signifikan sebesar 0.590 dan variabel empathy yang nilai signifikan sebesar o.113. penambahan variabel lain dalam menggali kepuasan konsumen atas kualitas layanan sistem informasi pajak kendaraan bermotor.
\end{abstract}

Kata kunci: kualitas layanan, e-government, SIZ, Pajak Kendaraan Bermotor

C) 2021 Penerbit Fakultas Teknik Unkhair. All rights reserved

\subsection{INTRODUCTION}

Pajak sebagai sumber pendapatan potensial bagi pemerintah. Dalam Undang-Undang No.28 tahun 2007 menjelaskan terkait ketentuan umum dan tata cara perpajakan, pajak didefinisikan pula sebagai kontribusi wajib pajak kepada Negara yang terutang oleh orang pribadi atau badan yang bersifat memaksa berdasarkan Undang-Undang, dengan tidak mendapat timbal balik secara langsung dan digunakan untuk keperluan Negara bagi sebesar-besarnya kemakmuran rakyat. 
Sehingga pajak merupakan iuran yang balas jasanya tidak dapat dirasakan secara langsung oleh wajib pajak. Hal tersebut dikarenakan pajak yang dibayarkan langsung masuk ke kas Negara dan dipergunakan dalam rangka kegiatan pembangunan Indonesia dan pembiayaan lainnya, [1].

Kantor Sistem Administrasi Manunggal Satu Atap (SAMSAT) sebagai institusi yang memberikan pelayanan jasa pembayaran pajak kendaraan bermotor yang didalamnya melibatkan tiga instansi yaitu Dispenda Provinsi, Polri, dan Jasa Rahaja. Saat ini Sistem informasi yang digunakan untuk melakukan pelayanan perpanjangan Surat Tanda Nomor Kendaraan (STNK) pada kantor SAMSAT kolaka adalah Sistem Informasi Samsat online (SIZ). Dimana dalam penerapannya Sistem Informasi Samsat online (SIZ) masih kurang maksimal dimana sering ditemukannya keluhanan terkait pelayanannya lama yang tidak sesuai dengan standar waktu yang ada.

Berdasarkan permasalahan di atas penting kiranya untuk mengetahui kualitas pelayanan sistem informasi SAMSAT Kabupaten Kolaka dengan menggunakan metode Servqual (service quality). Adapun Metode Servqual sendiri merupakan metode yang sering digunakan untuk mengukur kualitas pelayanan karena frekuensi penggunaannya yang tinggi, Servqual memenuhi syarat validitas secara statistik [2], [3], [4], [5], [6]. Metode servqual terdiri dari lima dimensi kualitas pelayanan, yaitu : Tangible (bukti terukur), reliability (keandalan), responsiveness (daya tanggap), assurance (jaminan), empathy (empati). Studi ini dapat dijadikan sebagai rekomendasi bagi pihak SAMSAT kolaka tentang kualitas pelayanan terhadap kepuasan konsumen saat ini sehingga dapat mengembangkan pelayanan.

\subsection{METODE}

Penggunaan metode SERVQUAL dalam penelitian ini adalah untuk mengetahui sejauh mana kualitas layanan sistem informasi SIZ yang diterapkan kantor SAMSAT kabupaten kolaka dengan Variabel Independen (Xn) antara lain : tangibles (X1), reliability (X2), responsiveness (X3), assurance(X4), emphaty (X5). Variabel dependen $(\mathrm{Y})=$ Kepuasan penerima layanan sistem. Dengan Responden 100 orang yang terdiri dari 50 orang pegawai SAMSAT yang menggunakan sistem dan 50 masyarakat yang menerima pelayanan dari sistem tersebut. Skala likert menggunakan ukuran data ordinal selanjutnya skor jawaban responden di jumlahakan dan dirata-ratakan menjadi skor rata-rata, skor inilah yang kemudian ditafsirkan sebagai posisi penilaian dalam skala likert. Kuesioner dengan skala likert (1-5) untuk mengetahui tingkat kepuasan konsumen terhadap pelayanan Samsat. Kepuasan konsumen menentukan adanya gap antara harapan konsumen dan tingkat layaknya yang diterima. Berikut tabel skala likert yang digunakan dalam studi ini:

Tabel 1 Ukuran Skala Likert

\begin{tabular}{crr}
\hline No & Expectation & \multicolumn{1}{c}{ Perception } \\
\hline 1 & Sangat tidak setuju : 1 & Sangat tidak setuju : 1 \\
\hline 2 & Tidak setuju : 2 & Tidak setuju : 2 \\
\hline 3 & Netral : 3 & Netral : 3 \\
\hline 4 & Setuju : 4 & Setuju : 4 \\
\hline 5 & Sangat setuju :5 & Sangat setuju :5 \\
\hline
\end{tabular}

Hasil analisis dari pengolahan kuesioner dijadikan rekomendasi yang dapat dinyatakan dalam nilai numerik yang mencerminkan tingkat kepentingan variabel. Penetapan besarnya nilai hasil ini didasarkan pada kesenjangan antara kepuasan harapan dan kepuasan yang diterima saat ini. Nilai kesenjangan negatif berarti lebih rendah dari yang diharapkan. Dan untuk mengidentifikasi pengaruh variable bebas terhadap variable terikat digunakan persamaan regresi linear berganda. Variable terikat (dependent variabel) dan sebagai variable bebas (independent variabel). desain kausal yang bertujuan untuk melihat pengaruh antara variabel bebas terhadap variable terikat. variabel bebas terdiri dari Tangibles (X1), Reliability (X2), Responsiveness (X3), Assurance (X4), dan Empathy (X5). Dan variabel terikat dari usulan penelitian ini adalah kepuasan konsumen (Y). Tahapan studi ini dapat dilihat pada gambar berikut: 


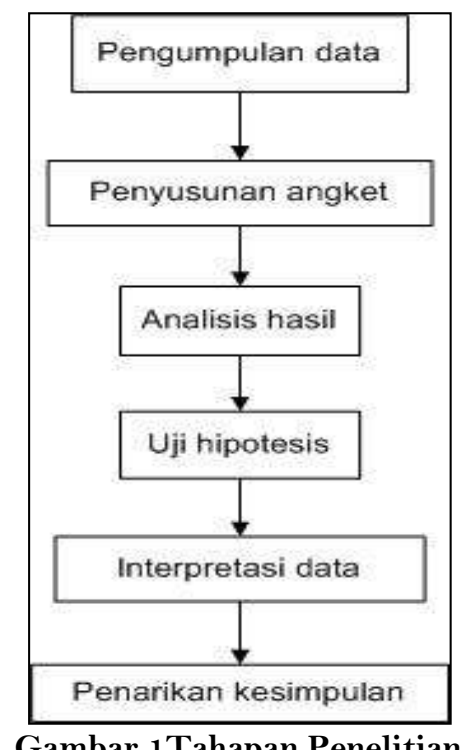

Gambar 1Tahapan Penelitian

\section{1 pengumpulan data}

Observasi dilakukan untuk menentukan tempat penelitian dan melakukan survey terhadap tempat dalam hal ini yaitu pada kantor SAMSAT Kolaka, proses wawancara pegawai dan konsumen yang menggunakan jasa pelayanan untuk memperoleh keterangan dan data-data yang diperlukan yang berkaitan dengan penelitian.

\subsection{Penyusunan Angket}

Penyusunan angket dengan yang bersumber dari studi kepustakaan yang nantinya akan diikutsertakan dalam analisis maupun sebagai dasar untuk menyusun kuesioner. Penyebaran kuisioner dengan cara mengedarkan daftar pertanyaan tertulis kepada responden yang telah ditetapkan. Penggunaan skala likert untuk mengidentifikasi tingkat kepuasan konsumen terhadap pelayanan Samsat. Kepuasan konsumen menentukan adanya gap antara harapan konsumen dan tingkat layaknya yang diterima.

\subsection{Analisis hasil}

Analisis hasil menggunakan metode SERVQUAL [3] dengan cara menganalisis gap antara tingkat harapan dan persepsi kualitas layanan sistem informasi pajak kendaraan Masing-masing responden diberikan dua jenis pertanyaan. Pertanyaan pertama mengenai tingkat harapan terhadap kualitas layanan sistem informasi pajak kendaraan. Pertanyaan kedua mengenai tingkat persepsinya terkait dengan kualitas layanan sistem informasi pajak kendaraan. Dari hasi yang diperoleh, maka bisa diketahui tingkat kualitas layanan system informasi pajak kendaraan dengan membandingkan hasil dari kedua pertanyaan tersebut [7]. Analisis hasil menggunakan:

\subsubsection{Uji Validitas}

Uji validitas untuk menguji apakah instrumen penelitian layak dijadikan alat ukur penelitian [7].

$$
r_{x y}=\frac{N \sum X Y-\left(\sum X\right)\left(\sum Y\right)}{\sqrt{\left.\left\{N \sum X^{2}-\sum X\right)^{2}\right\}\left\{N \sum Y^{2}-\left(\sum Y\right)^{2}\right\}}}
$$

\subsubsection{Uji Reliabilitas}

Pengujian reabilitas menggunakan teknik belah dua (split half) yang dianalisis dengan rumus Sperman Brown [7].

$$
r_{1}=\frac{2 \cdot r_{b}}{1+r_{b}}
$$

\subsection{Uji Hipotesis}

Selanjutnya Uji hipotesis menggunakan asumsi regresi yang memberikan hasil yang representative. Uji asumsi yang digunakan dalam studi ini menggunakan software SPSS (Statistical Product and Service Solutions) [8]. Berikut kerangka konseptual yang diajukan merujuk pada [9] dalam studi ini: 


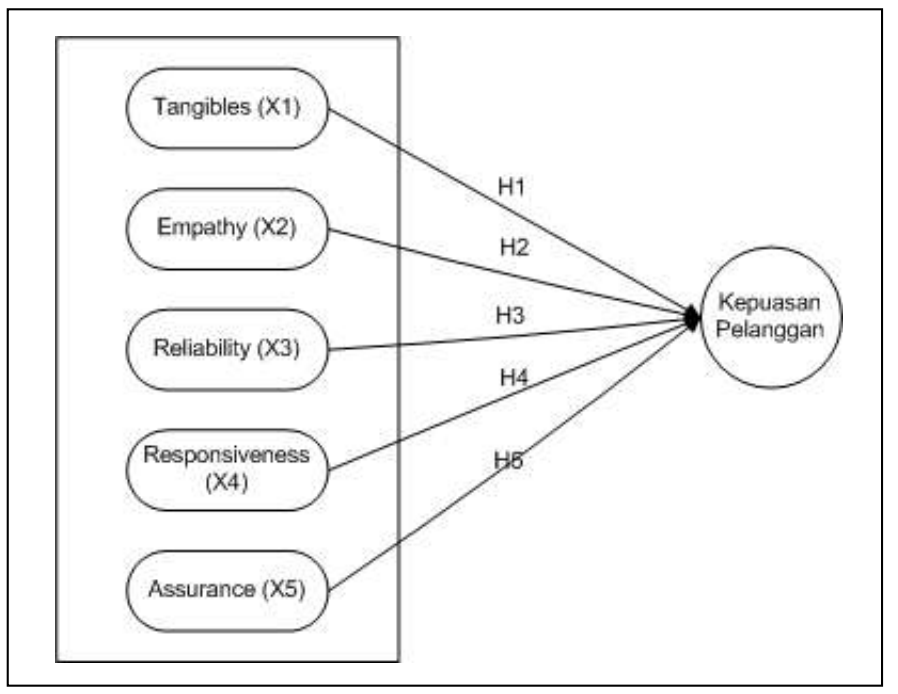

Keterangan :

Gambar 2 Kerangka Konseptual

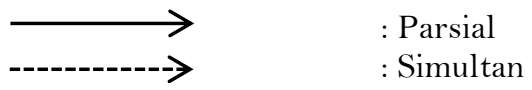

Hipotesis yang diajukkan

H1 :Tangible, empathy, reliability, responsiveness, assurance diduga berpengaruh signifikan terhadap kepuasan pelanggan pada kantor Samsat Kolaka.

H2 :Tangible diduga berpengaruh signifikan terhadap kepuasan pelanggan pada kantor Samsat Kolaka.

H3 :Empathy diduga berpengaruh signifikan terhadap kepuasan pelanggan pada kantor Samsat Kolaka.

H4 :Reliability diduga berpengaruh terhadap kepuasan pelanggan pada kantor Samsat Kolaka.

H5 :Responsiveness diduga berpengaruh signifikan terhadap kepuasan pelanggan pada kantor Samsat Kolaka.

H6 :Assurance diduga berpengaruh signifikan terhadap kepuasan pelanggan pada kantor Samsat Kolaka.

\subsection{Proses Interpretasi data}

Interpretasi data dengan menterjemahkan data kedalam bahasa yang mudah dipahami oleh orang lain.

\subsection{Penarikan Kesimpulan}

Kesimpulan berisi deskripsi singkat terkait hasil interpretasi data.

\subsection{Hasil dan Pembahasan}

Pengisian angket yang melibatkan 100 orang yang terdiri dari 50 orang pihak karyawan SAMSAT dan 50 orang masyarakat yang menerima layanan dari aplikasi SIZ dengan skala pengukurang menggunakan skala likert. Untuk menganalisis gap antara tingkat harapan dan persepsi kualitas layanan sistem informasi pajak kendaraan, maka digunakan uji f berpasangan. Masing-masing responden diberikan dua jenis pertanyaan. Pertanyaan pertama mengenai tingkat harapan terhadap kualitas layanan sistem informasi pajak kendaraan. Pertanyaan kedua mengenai tingkat persepsinya terkait dengan kualitas layanan sistem informasi pajak kendaraan.

\subsection{Uji Validitas}

Dari pengujian validitas diatas dapat dilihat bahwa dari 13 butir soal yang mewakili variabel x (variabel bebas) yaitu Kualitas Layanan Pajak Kendaraan terlihat nilai-nilai validitasnya, adapun dasar pengambilan keputusan yaitu apabila $r$ hitung $>$ rtabel maka butir soal dinyatakan valid dan dapat digunakan untuk penalitian, sebaliknya apabila $\mathrm{r}$ hitung $>$ rtabel maka butir soal dinyatakan tidak valid dan tidak dapat digunakan dalam penelitian. Nilai rtabel dapat dicari pada tabel nilai-nilai $\mathrm{r}$ product moment dengan ketentuan rtabel $=\mathrm{N}=50$ dan taraf signifikan yaitu $5 \%$ jadi nilai rtabel $=0,27$ dengan demikian butir soal pada variabel X dapat dinyatakan bahwa semuanya valid dengan melihat nilai rhitung dari semua item soal lebih besar dari nilai $r$ tabel.

Dari hasil pengujian validitas pada variabel y diperoleh nilai $r$ hitung $>$ nilai $r$ tabel. Nilai $r$ hitung di peroleh dari hubungan antara jawaban responden dengan skor total jawaban responden dengan menggunakan perintah correl pada excel sedangkan untuk nilai $r$ tabel di peroleh dari nilai product moment. Dengan demikian dapat di simpulkan bahwa variabel Y yang butir soalnya berjumlah 7 item semuanya valid karena nilai $r$ hitung tiap butir pertanyaan yaitu $p 1(0,540)$, p2(0,541), p3(0,435), p4(0,679), p5 (0,62), p6(0,627), p7(0,54) lebih besar dari pada nilai r tabel yang berjumlah $(0,279)$. 


\subsection{Uji Reliabilitas}

Setelah melakukan uji validitias maka langkah selanjutnya adalah menghitung nilai koefisien korelasi dan dalam penelitian ini diperoleh angka sebesar $=0,663$. Koefesien korelasi ini kemudian dimasukkan dalam rumus Spearman Brown seperti dibawah ini:

$r_{1}=\frac{2 \cdot r_{b}}{1+r_{b}}$

$r_{1}=\frac{2 * 0,663}{1+0,663}$

$\mathrm{r}_{1}=0,797$

Berdasarkan perhitungan yang telah di lakukan dengan menggunakan rumus Spearman Brown diperoleh nilai reabilitas dari seluruh instrument variabel Kualitas Pelayanan (X) sebesar 0,797 dan dapat di katakan realibel karena memiliki koefisien Crombach Alpha di atas 0,60. Pernyataan ini sesuai dengan [9] yang mensyaratkan bahwa suatu instrument yang reliabel jika memiliki koesien Crombach Alpha di atas 0,60.

Berdasarkan perhitungan yang telah di lakukan terhadap variabel Kepuasan Pengguna (Y) dengan menggunakan rumus Spearman Brown diperoleh nilai reabilitas dari seluruh instrument sebesar 0,603 dan dapat di katakana reabil karena memiliki koefisien Crombach Alpha di atas 0,60.

\subsection{Analisis SERVQUAL}

Mengacu pada [9], [10] diperoleh hasil yang menunjukan bahwa tingkat kualitas layanan system informasi pajak kendaraan memperoleh gap sebagai berikut:

Tabel 2 Analisis SERVQUAL

\begin{tabular}{|c|c|c|c|c|}
\hline Dimensi & No & Perception & expectation & $\operatorname{Gap}(\mathrm{P}-\mathrm{H})$ \\
\hline \multirow{4}{*}{ Tangibels } & 1 & 4.24 & 4.7 & -0.46 \\
\hline & 2 & 4.24 & 4.68 & -0.44 \\
\hline & 3 & 4.68 & 4.36 & -0.34 \\
\hline & 4 & 4.34 & 4.76 & -0.42 \\
\hline Rata-rata & \multicolumn{4}{|c|}{-0.415} \\
\hline \multirow{2}{*}{ Reliability } & 5 & 4.56 & 4.76 & -0.2 \\
\hline & 6 & 4.58 & 4.76 & -0.18 \\
\hline Rata-rata & \multicolumn{4}{|c|}{-0.19} \\
\hline \multirow{3}{*}{ Responsiveness } & 7 & 4.36 & 4.74 & -0.38 \\
\hline & 8 & 4.5 & 4.8 & -0.3 \\
\hline & 9 & 4.6 & 4.78 & -0.18 \\
\hline Rata-rata & \multicolumn{4}{|c|}{-0.28667} \\
\hline \multirow{3}{*}{ Assurance } & 10 & 4.34 & 4.82 & -0.48 \\
\hline & 11 & 4.68 & 4.84 & -0.16 \\
\hline & 12 & 4.52 & 4.68 & -0.16 \\
\hline Rata-rata & \multicolumn{4}{|c|}{-0.26667} \\
\hline Empathy & 13 & 4.6 & 4.94 & -0.34 \\
\hline Rata-rata & -0.1 & & & \\
\hline \multirow[t]{7}{*}{ Variabel Y } & 1 & 4.24 & 4.76 & -0.52 \\
\hline & 2 & 4.24 & 4.7 & -0.46 \\
\hline & 3 & 4.36 & 4.74 & -0.38 \\
\hline & 4 & 4.34 & 4.7 & -0.36 \\
\hline & 5 & 4.56 & 4.8 & -0.24 \\
\hline & 6 & 4.58 & 4.78 & -0.2 \\
\hline & 7 & 4.36 & 4.76 & -0.4 \\
\hline Rata-rata & \multicolumn{4}{|c|}{-0.36571} \\
\hline
\end{tabular}

Berdasarkan hasil perhitungan statistik seperti yang ditunjukkan pada Tabel 2 diatas diketahui gap antara harapan dan persepsi dari kualitas layanan sistem informasi pajak kendaraan untuk masing-masing dimensi Servqual dan variabel Y dari kepuasan konsumen. Berikut ini adalah hasil dari analisis gap untuk masing-masing dimensi.

Pertanyaan 1 sampai 4 mengacu pada variabel tangibels dengan rata-rata gap yang diperoleh sebesar -0.415. Tingkat harapan para pengguna terhadap variabel tangibels pada layanan sistem informasi pajak kendaraan dapat dikatakan tinggi 
karena rata-rata responden memberikan penilaian "setuju” dan "sangat setuju”. Dan pada tingkat persepsi, rata-rata responden juga menjawab "setuju” dan "sangat setuju” namun ada beberapa responden yang merasa belum puas dengan layanan yang diberikan sehingga menghasilkan nilai negatif pada perhitungan gap. Hal ini berarti memang terdapat perbedaan antara persepsi dan harapan terkait kualitas layanan sistem informasi pajak kendaraan bermotor pada Kantor Samsat.

Pertanyaan 5 sampai 6 mengacu pada variabel reliability dengan rata-rata gap yang diperoleh sebesar -0.19. Tingkat harapan para pengguna terhadap variabel reliability pada layanan sistem informasi pajak kendaraan dapat dikatakan tinggi karena rata-rata responden memberikan penilaian "setuju" dan "sangat setuju". Dan pada tingkat persepsi, rata-rata responden juga menjawab "setuju" dan "sangat setuju” namun ada beberapa responden yang merasa belum puas dengan layanan yang diberikan sehingga menghasilkan nilai negatif pada perhitungan gap. Hal ini berarti memang terdapat perbedaan antara persepsi dan harapan terkait kualitas layanan sistem informasi pajak kendaraan bermotor pada Kantor Samsat.

Pertanyaan 7 sampai 9 mengacu pada variabel responsiveness dengan rata-rata gap yang diperoleh sebesar -0.28667. Tingkat harapan para pengguna terhadap variabel responsiveness pada layanan sistem informasi pajak kendaraan dapat dikatakan tinggi karena rata-rata responden memberikan penilaian "setuju" dan "sangat setuju”. Dan pada tingkat persepsi, rata-rata responden juga menjawab "setuju” dan "sangat setuju” namun ada beberapa responden yang merasa belum puas dengan layanan yang diberikan sehingga menghasilkan nilai negatif pada perhitungan gap. Hal ini berarti memang terdapat perbedaan antara persepsi dan harapan terkait kualitas layanan sistem informasi pajak kendaraan bermotor pada Kantor Samsat.

Pertanyaan 10 sampai 12 mengacu pada variabel assurance dengan rata-rata gap yang diperoleh sebesar -0.26667. Tingkat harapan para pengguna terhadap variabel assurance pada layanan sistem informasi pajak kendaraan dapat dikatakan tinggi karena rata-rata responden memberikan penilaian "setuju” dan "sangat setuju”. Dan pada tingkat persepsi, rata-rata responden juga menjawab "setuju” dan "sangat setuju” namun ada beberapa responden yang merasa belum puas dengan layanan yang diberikan sehingga menghasilkan nilai negatif pada perhitungan gap. Hal ini berarti memang terdapat perbedaan antara persepsi dan harapan terkait kualitas layanan sistem informasi pajak kendaraan bermotor pada Kantor Samsat.

Pertanyaan 13 mengacu pada variabel empathy dengan rata-rata gap yang diperoleh sebesar -0.34. Tingkat harapan para pengguna terhadap variabel empathy pada layanan sistem informasi pajak kendaraan dapat dikatakan tinggi karena ratarata responden memberikan penilaian "setuju" dan "sangat setuju”. Dan pada tingkat persepsi, rata-rata responden juga menjawab "setuju" dan "sangat setuju" namun ada beberapa responden yang merasa belum puas dengan layanan yang diberikan sehingga menghasilkan nilai negatif pada perhitungan gap. Hal ini berarti memang terdapat perbedaan antara persepsi dan harapan terkait kualitas layanan sistem informasi pajak kendaraan bermotor pada Kantor Samsat.

Pertanyaan 1 sampai 7 mengacu pada variabel Y dengan rata-rata gap yang diperoleh sebesar -0.36571. Tingkat harapan para pengguna terhadap variabel Y pada kepuasan konsumen dapat dikatakan tingggi karena rata-rata responden memberikan penilaian "setuju" dan "sangat setuju". Dan pada tingkat persepsi, rata-rata responden juga menjawab "setuju" dan "sangat setuju” namun ada beberapa responden yang merasa belum puas dengan layanan yang diberikan sehingga menghasilkan nilai negatif pada perhitungan gap. Hal ini berarti memang terdapat perbedaan antara persepsi dan harapan terkait kepuasan konsumen yang meneriama pelayanan dari sistem informasi layanan pajak pada Samsat Kolaka.

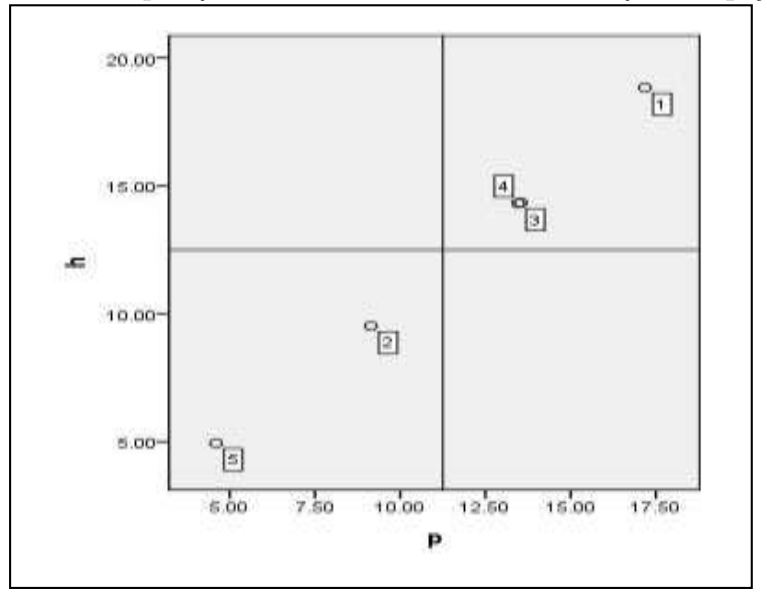

Gambar 3 Gap SERVQUAL pada dimensi Kualitas Pelayanan (X)

Adapun interprestasi dari gambar diatas yaitu :

1)Dimensi 1,4, dan 3 merupakan golongan variabel yang perlu diperbaiki dan perlu dipertahankan karena pengguna yang menggunakan sistem telah puas dengan layanan dari pajak kendaraan tersebut yaitu (SIZ Online). 2) Dimensi 2 dan 5 merupakan daerah perioritas yang rendah karena variabel yang terdapat pada variabel ini (variabel reliability dan variabel empathy) dianggap kurang atau tidak penting oleh pengguna dan pelayanannya kurang memusakan akan tetapi bukan 
berarti variabel ini tidak menjadi hal yang harus diperhatikan karena dimasa yang akan datang pernyataan atau atribut tersebut bisa menjadi hal yang dibutuhkan dalam menjalankan kualitas pelayananannya.

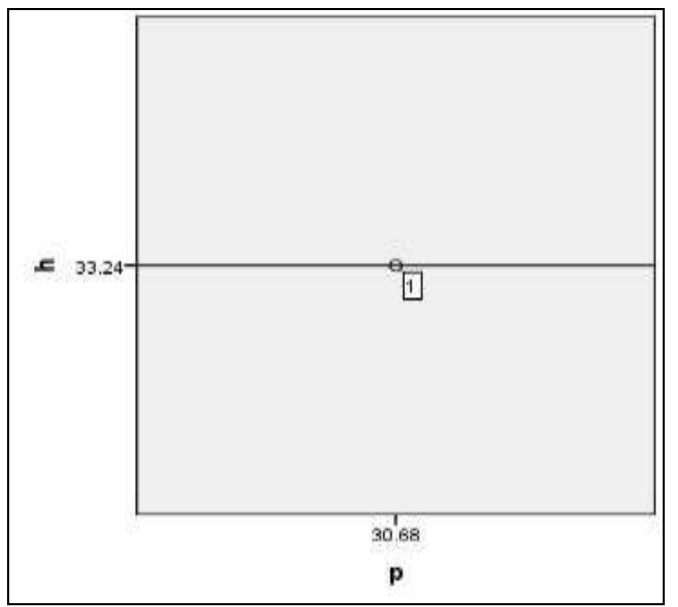

Gambar 4 Gap SERVQUAL pada dimensi Kepuasan Pengguna (Y)

Berdasarkan Gambar diatas terdapat faktor-faktor yang tidak terlalu penting dan tidak terlalu diharapkan oleh konsumen sehingga perusahaan ataupun kantor tersebut lebih baik mengalokasikan sumber daya yang terkait pada faktor tersebut pada faktor lain yang lebih memiliki tingkat perioritas yang lebih tinggi.

\subsection{Analisis Regresi Linear Berganda}

Table 1 Summary Model

\begin{tabular}{l|c|c|c|c}
\hline \multicolumn{4}{l}{ Model Summary } \\
\hline Model & $\mathrm{R}$ & $\mathrm{R}$ Square & $\begin{array}{l}\text { Adjusted } \\
\text { R Square }\end{array}$ & $\begin{array}{l}\text { Std. Error of the } \\
\text { Estimate }\end{array}$ \\
\hline 1 & $0,867^{\mathrm{a}}$ & 0,752 & 0,723 & 0,09862 \\
\hline \multicolumn{5}{l}{ a. Predictors: (Constant), X5, X2, X1, X3, X4 } \\
\hline
\end{tabular}

Tabel ini menjelaskan besarnya nilai korelasi/hubungan (R) yaitu sebesar 0,867 dan dijelaskan besarnya presentase pengaruh pengaruh variabel bebas terhadap variabel terikat yang disebut koefisien determinasi yang merupakan hasil dari penguadratan R. Dari output tersebut diperoleh koefisien deteterminasi (R2) sebesar 0,752 yang mengandung pengertian bahwa pengaruh variabel bebas (X1, X2, X3, X4, X5) terhadap variabel terikat (Y) adalah sebesar 75,2\% sedangkan sisanya dipengaruhi variabel lain.

Table 2 Uji ANOVA

\begin{tabular}{|c|c|c|c|c|c|}
\hline \multicolumn{6}{|l|}{ ANOVA $^{a}$} \\
\hline Model & Sum of Squares & Df & $\begin{array}{l}\text { Mean } \\
\text { Square }\end{array}$ & $\mathrm{F}$ & Sig. \\
\hline 1 Regression & 1,295 & 5 & 0,259 & 26.626 & 0,000 \\
\hline Residual & 0,428 & 44 & 0,010 & & \\
\hline Total & 1,723 & 49 & & & \\
\hline a. Dependent I & le: Y & & & & \\
\hline b. Predictors: ( & $\tan \mathrm{t}), \mathrm{X} 5, \mathrm{X} 2, \mathrm{X} 1$, & $\mathrm{X} 4$ & & & \\
\hline
\end{tabular}

Tabel uji F digunakan untuk mengetahui apakah variabel independen secara simultan berpengaruh signifikan terhadap variabel dependen. Derajat kepercayaan yang digunakan adalah 0,05. Hasil dari uji F pada gambar menunjukkan bahwa

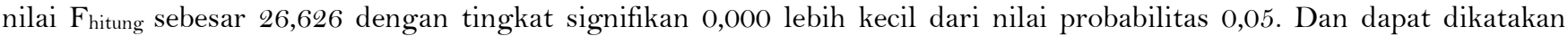
bahwa semua variabel independen secara simultan berpengaruh signifikan terhadap variabel dependen.

Table 3 Uji Koefisien

\begin{tabular}{lllll}
\hline Coefficients $^{\mathbf{a}}$ & \multicolumn{4}{c}{} \\
Model & $\begin{array}{l}\text { Unstandardized } \\
\text { Coefficients }\end{array}$ & $\begin{array}{l}\text { Standardized } \\
\text { Coefficients }\end{array}$ & Sig. \\
\cline { 2 - 4 } & $\mathrm{B}$ & Std. & Beta & \\
& Error & & \\
\hline
\end{tabular}




\begin{tabular}{cllllll}
\hline 1 & (Constant) & 1.091 & 0,389 & & 2,802 & 0,008 \\
\cline { 2 - 7 } & $\mathrm{X} 1$ & 0,381 & 0,076 & 0,426 & 5,040 & 0,000 \\
\cline { 2 - 7 } & $\mathrm{X} 2$ & 0,234 & 0,040 & 0,462 & 5,851 & 0,000 \\
\hline $\mathrm{X} 3$ & 0,265 & 0,065 & 0,333 & 4,104 & 0,000 \\
\hline $\mathrm{X} 4$ & 0,042 & 0,071 & 0,052 & 0,590 & 0,558 \\
\hline & $-0,067$ & 0,041 & $-0,131$ & -1.617 & 0,113 \\
\hline
\end{tabular}

a. Dependent Variable: Y

Uji koefisien dilakukan untuk mengukur seberapa besar kontribusi variabel terikat kepada variabel bebas [8] tabel 3 menunjukan hal sebagai berikut:

1. Pengaruh variabel tangibels terhadap kepuasan konsumen

Berdasarkan hasil regresi pada Tabel 16 diperoleh hasil uji t hitung untuk variabel tangibels sebesar 5.040 dengan tingkat signifikan 000 yang lebih kecil dari 0.05. berdasarkan kriteria tersebut tangibels secara parsial berpengaruh terhadap kepuasan konsumen.

2. Pengaruh variabel reliability terhadap kepuasan konsumen

Nilai t hitung pada variabel reliability sebesar 5.851 dengan tingkat signifikan 0,00 yang lebih kecil 0.05 berdasarkan kriteria tersebut reliability berpengaruh terhadap kepuasan konsumen.

3. Pengaruh variabel responsiveness terhadap kepuasan konsumen

Nilai t hitung pada variabel responsiveness sebesar 4.104 dengan tingkat signifikan 0,00 yang lebih kecil 0.05 berdasarkan kriteria tersebut reliability berpengaruh terhadap kepuasan konsumen.

4. Pengaruh variabel assurance terhadap kepuasan konsumen

Nilai t hitung pada variabel assurance sebesar 0.590 dengan tingkat signifikan 0.558 yang lebih besar dari 0.05 berdasarkan kriteria tersebut assurance tidak berpengaruh terhadap kepuasan konsumen.

5. Pengaruh variabel empathy terhadap kepuasan konsumen

Nilai t hitung pada variabel empathy sebesar dengan tingkat signifikan 0.113 yang lebih besar dari 0.05 berdasarkan kriteria tersebut assurance tidak berpengaruh terhadap kepuasan konsumen.

\subsection{Uji Hipotesis}

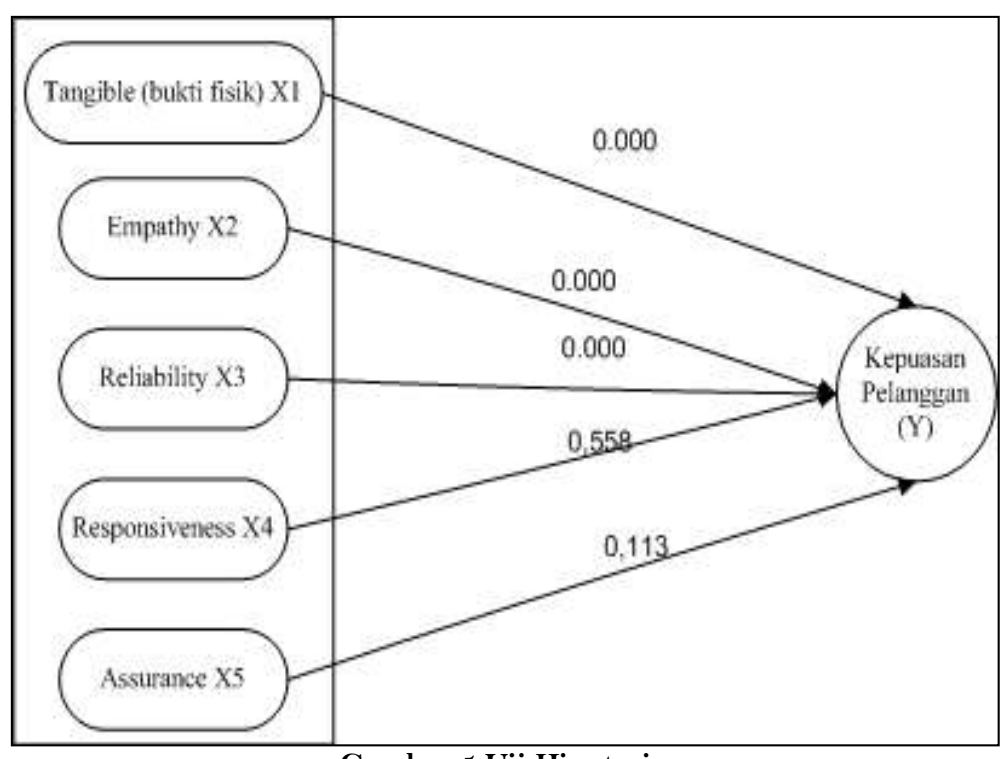

Gambar 5 Uji Hipotesis

Berdasarkan Gambar diatas dapat dilihat bahwa ada beberapa garis yang berbeda. Pada variabel tangibels, reability, responsiveness terdapat garis yang tidak terputus yang berarti bahwa ada pengaruh terhadap kepuasan konsumen dan pada variabel assurance dan empathy terdapat garis putus yang berarti bahwa variabel tersebut tidak berpengaruh terhadap kepuasan konsumen. Adapun pengujian yang dilakukan secara serentak (simultan) terdapat pengaruh pada kepuasan konsumen. 


\subsection{CONCLUSION}

berdasarkan hasil perhitungan statistik ditemukan kualitas layanan sistem informasi pajak kendaraan bermotor pada kantor samsat kolaka masih kurang memuaskan terutama dimensi 2 dan 5 merupakan daerah perioritas yang rendah karena variabel yang terdapat pada variabel ini dianggap kurang atau tidak penting oleh pengguna dan pelayanannya kurang memusakan akan tetapi bukan berarti variabel ini tidak menjadi hal yang harus diperhatikan karena dimasa yang akan datang pernyataan atau atribut tersebut bisa menjadi hal yang dibutuhkan dalam menjalankan kualitas pelayananannya.

Berdasarkan hasil perhitungan statistik terdapat gap antara persepsi dan harapan dari kualitas layanan sistem informasi pajak kendaraan untuk masing-masing dimensi Servqual, dimana pada variabel tangibels terdapat rata-rata gap sebesar ($0.415)$, reability (-0.19), responsiveness (-0.28667), assurance (-0.26667), empathy (-0.17), dan variabel Y sebesar ($0.36571)$.

Dari perhitung regresi berganda yang menggunakan SPSS ada beberapa variabel yang tidak berpengaruh terhadap kepuasan konsumen karena nilai taraf signifikan yang lebih besar dari 0.05 diantaranya variabel assurance dengan nilai signifikan sebesar 0.590 dan variabel empathy yang nilai signifikan sebesar 0.113.

\section{References}

[1] ani. (2019, april) https:/etalasepustaka.Blogspot.com/2016/05/ pengertian-pajak-menurut-uu-nomor-28-tahun-2007.Html. [Online]. https:/etalasepustaka.Blogspot.com

[2] Dewi A, Febi S.N, "Analisis Kualitas Layanan E-commerce Terhadap Kepuasan Pelanggan Menggunakan Metode E-servqual," Jurnal Rekayasa dan Manajemen Sistem Informasi, 2016.

[3] Fathoni, "Analisis Kualitas Layanan Sistem Informasi Menggunakan Metode Servqual," in Konferensi Nasional Sistem dan Informatika, Palembang, 2009.

[4] Marlindawati, "Analisis Kualitas Layanan Sistem Informasi Menggunakan Servqual Method," in Seminar Nasional Aplikasi Teknologi Informasi, 2013.

[5] G,S Melia, "Analisis Sistem Informasi Aplikasi Online Kartu Kredit Menggunakan Metode Servqual," Jurnal Telekomunikasi dan Komputer, 2015.

[6] Wahyu, P,H. Leon, A,B. Fatmasari, "Analisis Kualitas Tokopedia Menggunakan Metode ServQual," universitas binadarma, palembang, skripsi 2016.

[7] Sugiyono, Metode Penelitian Kuantitatif, Kualitatif. Bandung: Alfabeta, 2015.

[8] sppsindonesia. (2019, juni) Https://www.spssindonesia.com/2014/o2cara-mudah-melakukan-uji-t-dengan spss.html. [Online]. Https://www.spssindonesia.com

[9] Zeihmal et. al, Service Mar keting Avenue Of The Americas, Fifth Edition ed. Newyork, USA: The Mc Graw-Hill Companies, 2009.

[10] Zeithaml, L. Valerie A., Parasuraman, A., Berry, Leonardo L, "'Servqual; A Multiple Item Scale for Measuring Consumer Perception of Service Quality"," Journal and Retailing, Springer page, vol. Vol. 64, pp. 12-40, 1988. 